\title{
CALIFORNIA'S PREDELINQUENCY STATUTE: A CASE STUDY AND SUGGESTED ALTERNATIVES
}

The tendency to defime antisocial behavior in terms of moral values is nowhere more evident than in statutes regulating juvenile conduct. In California, Welfare and Institutions Code sections 600, 601, and 602 permit juvenile courts to assume jurisdiction over juveniles who are dependent or neglected; ${ }^{1}$ who are in danger of leading an idle, lewd, dissolute, or immoral life, or who are beyond parental control; ${ }^{2}$ or who have violated state or federal law. ${ }^{3}$ While these sections reflect the state's concern for preventing and treating delinquency, they also permit broad juvenile court intrusion into the personal affairs of a very large number of minors. Since section 601 is phrased broadly and permits flexible imterpretation by judges, even innocent juvenile conduct inay be within its reach. ${ }^{4}$ Not all are caught

1. Cal. Welf. \& INst'Ns Code ANN. \$ 600 (West 1966):

Persons subject to jurisdiction. Any person under the age of 21 years who comes within any of the following descriptions is within the jurisdiction of the juvenile court which may adjudge such person to be a dependent child of the court:

(a) Who is in need of proper and effective parental care or control and has no parent or guardian, or has no parent or guardian willing to exercise or capable of exercising such care or control, or has no parent or guardian actually exercising such care or control.

(b) Who is destitute, or who is not provided with the necessities of life, or who is not provided with a home or suitable place of abode, or whose home is an unfit place for him by reason of neglect, cruelty, or depravity of either of his parents, or of his guardian or other person in whose custody or care he is.

(c) Who is physically dangerous to the public because of a mental or physical deficiency, disorder or abnormality.

2. CAL. Welf. \& INST'NS CODE ANN. \$ 601 (West 1966):

Minors habitually refusing to obey parents; habitual truants; minors in danger of leading immoral life. Any person under the age of 21 years who persistently or liabitually refuses to obey the reasonable and proper orders or directions of his parents, guardian, custodian or school authorities, or who is beyond the control of such person, or any person who is a habitual truant from school within the meaning of any law of this State, or who from any cause is in danger of leading an idle, dissolute, lewd, or immoral life, is within the jurisdiction of the juvenile court which may adjudge such person to be a ward of the court.

3. CAL. Welf. \& INST'NS CODE ANN. $\S 602$ (West 1966):

Minors violating laws defining crime; minors failing to obey court order. Any person under the age of 21 years who violates any law of this State or of the United States or any ordinance of any city or county of this State defining crime or who, after liaving been found by the juvenile court to be a person described by Section 601, fails to obey any lawful order of the juvenile court, is within the jurisdiction of the juvenile court, which may adjudge such person to be a ward of the court.

4. Monrad Paulsen views statutes that give broad discretionary powers with 
or referred, of course, but this depends almost wholly on parental leniency and understanding. ${ }^{5}$

This Comment discusses section 601 in its historical context and in the context of police action against transient juveniles in Berkeley, California, in the summer of 1970. It concludes that section 601 is obsolete and should be replaced with programs and procedures that offer counseling rather than juvenile hall for noncriminal conduct.

Part I discusses the historical background of delinquency and predelinquency statutes. Part II presents the findings of an extensive study of how section 601 was used in Berkeley in 1970. Part III examines the underlying constitutional issues, showing the recent loss of faith in the juvenile courts' ability to protect basic rights. And part IV suggests several alternatives to the present treatment of nondelinquent youth that preserve the distinction between criminal and noncriminal conduct.

\section{ThE Historical BaCKGRound}

Under the common law, children under seven were considered incapable of forming the intent necessary to commit a crime; but children over the age of seven were subject to arrest, trial, and, in theory, punishment, like adult offenders. ${ }^{6}$ In response to the treatment of young offenders, humane societies in the early 1800's established homes to reform young criminals, ${ }^{7}$ and by the late 1800 's a conscious effort had been undertaken to estabhish a separate system of justice

suspicion:

Jurisdictional formulations of delinquency often include vague phrases such as "engaging in conduct harmful to himself or others", "incorrigibile" or "a child who is beyond the control of his parents or other custodian." Certainly such inperial language has formed the basis for adjudication of delinquency in the case of Negro children engaged in civil right demonstrations. One suspects that they can be used generally against the children of the poor. . . .

Legislation does note choose the children who are actually brought into juvenile court. The decision whether to bring a certain boy in . . . is ordinarily within the sole province of the man on the beat.

M. Paulsen, Juvenile Courts, Family Courts, and the Poor Man 9 (unpublished, prepared for the Conference on The Law of the Poor, University of California, Berkeley, 1966). See also Tappan, Judicial and Administrative Approach to Children with Problems, in JUSTICE FOR THE CHILD 156-57 (M. Rosenheim ed. 1962).

5. See text accompanying note 30 infra.

6. Mack, The Chancery Procedure in the Juvenile Court, in THE CHIL, THE ClINIC, AND THE CoURT 310 (J. Addams ed. 1925) [this volume hereinafter cited as The Chrld, the Clinic, AND the Covrt].

7. For example, the New York House of Refuge was founded by the Society for the Reformation of Juvenile Delinquents. See Fifth Annual Report, 1830, in DELINQUENCY AND Social PoliCY 12 (P. Lerner ed. 1970). 
for juveniles. This concern for juveniles was one part of the awakening of middle-class intellectuals to the poverty of large urban centers. $^{8}$ One of the products of this "child saving" movement was the juvenile court systein. ${ }^{9}$

While the thrust of the "child savers" was directed toward the removal of adolescents from the criminal law process and the creation of special programs for delinquent, dependent, and neglected children, the reformers also sought a reaffirmation of faith in traditional virtues, such as parental authority, education at home, and the values of rural life. Professor Anthony Platt describes the movement as:

in part, a crusade which, through emphasizing the dependence of the social order on the proper socialization of children, implicitly elevated the nuclear family, and, more especially, the role of women as stalwarts of the family.10

What began as an effort to humanize the treatment of youthful offenders, however, soon evolved into a crusade for moral purity. Thus, much of the movement's attention came to be focused on preventimg crime by training potential criminals in the habits of industry, selfcontrol, and obedience to the law. ${ }^{11}$ Rather than simply placing a juvenile offender under the jurisdiction of the juvenile court in the place of the normal criminal courts, the movement also undertook to identify potential delinquents through precriminal behavior, incorrigibility, truancy, or disobedience. Furthermore, juvenile courts often took jurisdiction when it was felt that the parents and not the children had misbehaved, as for example, if the parents were deemed idle, ignorant, or imdigent. ${ }^{12}$

The first juvenile court statute was adopted in Illinois in $1899,{ }^{13}$ and similar statutes were later adopted by all the states. ${ }^{14}$ They uni-

\footnotetext{
8. A. Platt, The Child Savers 41 (1969).

9. Id. at 137-38.

10. Platt, The Rise of the Child Saving Movement: A Study in Social Policy and Correctional Reform, 381 The ANNALs 21, 27 (1969). (1909).

11. Id. at 38. See also Mack, The Juvenile Court, 23 Harv. L. Rev. 104, 120

12. As one court put it:

It would be carrying the protection of "inalienable rights," guaranteed by the Constitution, a long ways to say that that guarauty extends to a free and unlimited exercise of the whims, caprices, or proclivities of either a child or its parents or guardians for idleness, ignorance, crime, indigence, or any kindred dispositions or inclinations.

Ex parte Sharp, 15 Idaho 120, 129-30, 96 P. 563, 565 (1908). See generally Mack, The Juvenile Court, 23 HaRv. L. Rev. 104 (1909).

13. R. Cavan, Juvenile Delinguency 234-36 (1962); Hurley, Origin of the Illinois Juvenile Court Law, in The CHIL, The ClINIC, AND The Court 320, 325-29; Mack, The Juvenile Court, 23 HARv. L. Rev. 104, 107 (1909).

14. See National Council of Juventle Court Judges, Directory and Manual 1 (1964). Cf. R. CAvan, supra note 13, at 234-36 (1962); Hurley, supra note 13 at 329.
} 
formly gave the juvenile court judges almost unlimited discretion. Traditional procedural safeguards were considered unnecessary in juvenile court, because the proceedings were characterized as civil and in parens patriae; ${ }^{15}$ that is, in place of the parents. The argument that, since natural parents were not limited by due process, neither should the juvenile court be, ${ }^{16}$ was expressed in one of the earliest decisions:

The natural parent needs no process to temporarily deprive his child of its liberty by confining it in his own loome, to save it and to shield it from the consequences of persistence in a career of waywardness, nor is the state when compelled, as parens patria, to take the place of the father for the same purpose, required to adopt any process as a means of placing its hands upon the child. . . . The court . . . determines [the child's] salvation, not its punishment. ${ }^{17}$

It was not until the United States Supreme Court decisions in Kent v. United States ${ }^{18}$ and In re Gault ${ }^{19}$ that this relaxation of procedural requireinents was subjected to successful attack. The Kent Court admonished that "to function in a parental relationship is not an invitation to procedural arbitrariness." ${ }^{20}$ The Court went on to

15. The phrase parens patriae originated in chancery practices where it described the power of the state to act in loco parentis for the purpose of protecting the property interests and the person of the child. Mack, The Juvenile Court, 23 HARv. L. REv. 104,109 (1909). It is based on the presumption that the interests of the state and the welfare of the child are not in conflict. Therefore, it is further presumed that the state, as substitute parent, will act in the best interest of the child. Ketcham, The Unfulfilled Promise of the American Juvenile Court, in JUSTICE FOR THE CHILD 38 (M. Rosenheim ed. 1962). See also Paulsen, Kent v. United States: The Constitutional Context of Juvenile Cases, 1966 SuP. CT. REv. 167, 174.

There was apparently little constitutional objection to the special procedures of the juvenile court. But see Waite, How Far Can Court Procedure be Socialized without Impairing Individual Rights, 12 J. CRIM. L. \& CRIMINology 339, 340 (1921):

The court which must direct its procedure even apparently to do solnething to a child because of what he has done, is parted from the court which is avowedly concerned only with doing something for a child because of what he is and needs, by a gulf too wide to be bridged by any humanity which the judge may introduce into his hearings, or by the habitual use of corrective rather than punitive methods after conviction.

16. See Paulsen, Fairness to the Juvenile Offender, 41 MiNs. L. REv. 547, 551 (1957); Note, Rights and Rehabilitation in the Juvenile Court, 67 CoLUM. L. Rev. 281, 309 (1967).

17. Commonwealth v. Fisher, $213 \mathrm{~Pa} .48,53,62$ A. 198, 200 (1905).

18. 383 U.S. 541 (1966). Kent was the first juvenile court case to be heard by the Supreme Court. Justice Fortas, writing for the Court, observed:

There is evidence, in fact, that there may be grounds for concern that the child receives the worst of both worlds: that he gets neither the protections accorded to adults nor the solicitous care and regenerative treatment postulated for children.

Id. at 556. For an interesting view of this case see Bazelon, Justice for Juveniles, The New Republic, April 22, 1967, at 13.

19. 387 U.S. 1 (1967).

20. 383 U.S. at 555 . 
hold that due process required a hearing before a juvenile could be remanded from juvenile court to adult court. $^{21}$ Extending this rationale, the Court held in Gault a year later that a juvenile and his parents must be given notice sufficient to permit preparation for a defense to the charges; notified of the child's right to be represented by counsel, including assigned counsel; and afforded the privilege against self-incrimination, the right to confrontation, and cross-exainination of witnesses against him. ${ }^{22}$

Despite persistent criticisms and periodic efforts at reform, ${ }^{23}$ the present juvenile court system-at least in its statutory formulationlargely retains the basic precepts of the "child savers." 24 The first and inost coinprehensive effort at reform occurred in 1961, when the Governor of California appointed a special commission to study the operation of the juvenile courts. ${ }^{25}$ The Governor's Commission found a number of problems: the absence of well-defined decisionmaking standards to guide judges, probation, and law enforcement officers in the performance of their respective duties; inadequate protection of legal rights; inconsistencies in philosophy and lack of coordination among those responsible for administering the system; rehabilitation services too often based on expediency; unwarranted detentions; and ambiguities and contradictions in the law itself. ${ }^{26}$ As a result of this study, the legislature enacted substantial revisions of the applicable statutes. ${ }^{27}$ These revisions accorded to juveniles most of the rights that Gault later made applicable to juveniles in all states.

Although the revisions provided for greater and more uniform procedural safeguards, the juvenile court continued to be regarded primarily as a ineans to provide rehabilitation and counseling services. As one California judge describes his experiences:

I have had the distinct impression from time to time that as a juvenile court judge $I$ found myself acting as a glorified babysitter, a woefully inadequate substitute parent, an agency for advice to the lovelorn, a judicial truant officer and a general catch-all for many problems which should be handled and would be handled by the average family were they not able to turn over their responsibilities to the juvenile court. And I think each of us has suffered the frustrating experience of trying to oversee the sexual activities of a large

21. Id. at 553 .

22. 387 U.S. at 10.

23. See Note, The California Juvenile Court, 10 StAN. L. Rev. 471 (1958).

24. The California Code sections are examples. See text accompanying notes 1-3 supra.

25. California Juvenile Justice Commission, Report of The Special Study COMMISSION ON JUVENILE JUSTICE (1960).

26. Id. at 12.

27. CaL. Welf. \& Inst'Ns Code Ann. $\$ \S 609-914$ (West 1966) (added by ch. 1616, § 2, [1961 Cal. Stat. 3471]). 
group of uncooperative young ladies who were in danger of leading idle, lewd, dissolute or immoral kives' when they came before us and who were not much better when they left. 28

Therefore, the delineation of clearly defined procedures has not produced consistency in the substantive application of the law.

In addition to the procedural problem, there is another, to which only sporadic reform attempts have been directed: the jurisdictional scope of the juvenile courts. All three of the California jurisdictional statutes $^{29}$ cover a broad range of ages, from 7 to 21 years, although in actual practice a person over the age of 18 seldom comes before the court. ${ }^{30}$ Furthermore, simce the provisions of section 601 carry less severe consequences for the liberty of the child, ${ }^{31}$ the California supreme court lias suggested that it applies to a broad range of conduct, in effect functioning as a catcliall provision by wlich the juvenile court can acquire jurisdiction over any predelinquent child, ${ }^{32}$ that is, any child who cannot appreciate the wrongfulness of his conduct.

The rehabilitation possibilities for predelinquent children under section 601 are as wide-ranging as the group the statute purports to include. These clildren may be treated either as dependcnt children ${ }^{33}$ or as delinquent children, who may be committed to a juvenile facility or to the California Youth Authority, ${ }^{34}$ depending upon the severity of the offense.

\section{II}

\section{A Case Study: Berkeley's Use of Section 601 IN the SUMMER OF $1970^{*}$}

Berkeley's use of section 601 in the summer of 1970 presents a striking example of how broadly the statute can be applied in prac-

28. Gardner, Let's Take Another Look at the Juvenile Court, in Delinquency AND Social PolicY 257 (P. Lerner ed. 1970).

29. See Cal. Welf. \& Inst'ns Code ANn. $\$$ 600-02 (West 1966).

30. The adult courts have original jurisdiction over all persons over 18 who are charged with criminal law violations, and the juvenile court has original jurisdiction of all persons under 18. CAL. WeLf. \& INST'NS CODE ANN. \$ 603 (West 1966). As for sections 600 and 601, youths between 18 and 21 are generally not accepted by the probation department. With the recent passage of legislation according adult status to 18-year-olds, it is doubtful that any person over 18 could be referred to the juvenile court under sections 600 and 601 .

31. See CAL. Welf. \& Inst'NS Code ANN. $\$ \S 730-31$ (West 1966).

32. In re Gladys R., 1 Cal. 3d 855, 865 n.20, 464 P.2d 127, 135 n.20, 83 Cal. Rptr. 671, 679 n.20 (1969).

33. Cal. Welf. \& INST'NS CODE ANN. \& 730 (West 1966).

34. Cal. Welf. \& Inst'ns Code ANn. $\$ \S 730.777$ (West 1966). See also note 105 infra.

* This section is based in part on the author's experiences as a deputy probation officer in the Alanneda County Probation Department from 1965 to 1969 and during the summer of 1970 . 
tice and demonstrates the need for a more thorough legislative formulation of jurisdictional standards. Due in part to the free speech movement of the mid-1960's ${ }^{35}$ and to the activism of the student population, Berkeley became a haven for the young and unconventional, attracting large numbers of them each summer. These annual influxes swelled the population of "street people" and caused consternation among many of Berkeley's older residents, who claimed that the unwanted visitors were responsible for an increase in petty crimes and for the moral and physical degeneration of parts of the city.

The summer of 1970, like previous summers, witnessed an influx of young people. In response to this situation, the Berkeley Police Department employed a "runaway net"36 and detained and returned over 1,000 children to their parents. ${ }^{37}$ Anyone who appeared to be a nonresident of the city under the age of 18 and was unaccompanied by a responsible adult was subject to detention by the police. The purported purpose of the campaign was twofold: a paternalistic concern for the welfare of the young visitors; and a crime prevention measure. ${ }^{38}$ Berkeley Police Chief Bruce Baker offered this explanation of the policy:

When there are parents irresponsible enough to give a 13-yearold permission to travel across the country, society must have laws to protect those children.

We simply don't have the conditions and the facilities (in Berkeley) to handle the influx of juveniles. They are not arrested. They are picked up and returned to their parents. ${ }^{39}$

The roundup of youthful transients was conducted under section 601, which-unlike section 602-does not define its applicability in terms of criminal behavior. Instead, it is applicable to juveniles who are runaways, truants, beyond parental control, or who for any reason are in danger of leading an idle, dissolute, lewd, or immoral life. ${ }^{40}$ The Berkeley police argued that "beyond parental control," which usually had been used to refer to runaways (children who leave home without parental permission), should also refer to young transients, whether or not they had parental permission to travel. They thus concluded that any child beyond the physical control of his parents,

35. The free speech movement happened at the University of California, Berkeley in 1964. For a recounting of the important events, see R. O'NEIL, FRER SPEECH: Responsible COMMUNCATION UNDER LAW 11-12 (1966).

36. The label "runaway" was used as a generic rather than an exact term to describe those transient non-Berkeley youths under 18 years suspected of being in Berkeley without parental control.

37. Berkeley Gazette, Sept. 8, 1970, at 1, col. 6.

38. Berkeley Gazette, July 17, 1970, at 2, col. 3 .

39. Berkeley Gazette, Aug. 3, 1970, at 1, col. 8.

40. CAL. WEIF. \& INST'NS CODE ANN. $\$ 601$ (West 1966). 
even if he had written permission to travel, should be comprehended by section $601 . .^{41}$

The phrase "beyond parental control" has not been precisely construed by the courts in the context of section 601. In Marr v. Supcrior Court, ${ }^{42}$ the court said in construing former section 700 (b) (now section 600(a)):

Parental control means such control as parents ordinarily exercise and the phrase carries with it the implication of the purpose of parental control over such an infant, that is, its proper care and support, the usual incidents of the exercise of control over it.43

This definition, however, is unsatisfactory in section 601 cases because section 600 is the parental neglect section, to which the vague language concerning "proper care and support" is more relevant. The Marr definition speaks in terms of parental responsibility, while section 601 refers to children who refuse to accede to parental authority.

In In re David Arthur $S .{ }^{44}$ the court referred to this distinction in sustaining a wardship under section 601. The court interpreted the phrase "beyond parental control" as "defiance of parental authority." "W5 While a single act, if sufficiently serious, could indicate that a child is beyond control, the court warned against denying equal treatment to the young:

[I] the standards of conduct proscribed by section 601 are not care-

fully delineated, the statute could become a means of systematic discrimination against young people who are thereby denied equal protection of the law. ${ }^{48}$

Similarly, the California Governor's Commission on Juvenile Law warned that intervention is not warranted unless there is clear and competent proof of a tendency towards delinquency. ${ }^{47}$ At most under this definition, a roundup only of those who had come to Berkeley after having been denied parental permission to travel would have been statutorily permissible.

In the absence of a clear judicial definition of "beyond parental control," the Berkeley police apparently felt unrestrained in applying their own standards. An examination of the case files from the sum-

41. See Berkeley Gazette, July 17, 1970, at 1 , col. 1.

42. 114 Cal. App. 2d 527, 250 P.2d 739 (3d Dist. 1952).

43. Id. at 530,250 P.2d at 742 .

44. 12 Cal. App. 3d 1124, 91 Cal. Rptr. 261 (1st Dist. 1970).

45. Id. at 1126, 91 Cal. Rptr. at 262.

46. Id. at 1127, 91 Cal. Rptr. at 263. See Savoy, Toward a New Politics of Legal Education, 79 YAIE L.J. 444, 453-54 (1970) (arguing for abolishing special rules for regulating the conduct of adolescents because the vague laws deny equal protection). See also note 90 infra.

47. California Juvenile Justice Commission, supra note 27 , pt. 2, at 30. 
mer of 1970 revealed how little restraint there was on police conduct during the almost 2-month period, July 9 through August 31. ${ }^{48}$ Approximately 410 juveniles were referred to the Alameda County Probation Department by the Berkeley police, of whom only 112 were detained more than 48 hours. ${ }^{49}$ Concentrating their efforts in areas where young people congregate, ${ }^{50}$ the police typically approached anyone who appeared to be under the age of 18 who was carrying either a sleeping bag or knapsack. ${ }^{51}$ Anyone unable to produce identification or to establish his age or that he resided in Berkeley would be taken into custody $y^{52}$ and detained under section 601 . The police were reluctant to use the term "arrest" and preferred to refer to the detention as "protective custody." "53

48. The Alameda County Probation Department gave permission to examine the juveniles' files, and the authors examined all available case files of youths arrested and delivered to the probation department between July 9, 1970 and August 31, 1970.

49. The intake sheet at the Alameda County Probation Department indicated that from July 9 through August 31, 410 minors were delivered to the probation department by the Berkeley Police Department for "runaway." Three liundred and thirty-nine of these 410 files were available for review; the rest of the files could not be located. Many of the files gave no indication whether the minors had parental permission. Of the 233 files that indicated parental comments, 153 of the minors had some form of permission, and while 80 had no permission at all, most of these had not been reported to the police as runaways.

As for detention practices, 159 were detained for one day or less, 68 were detained for two days, 89 for three to six days, 15 for seven to nine days and only 8 for more than 10 days.

Of the dispositions made by the probation officer, only one minor was released on his own recognizance. Five were referred to local runaway agencies, 185 were transported lome at parental expense, 105 were released through other arrangements with parents, and there were 11 other miscellaneous dispositions. Section 601 petitions to make children watds of the court were filed in 32 cases; of these, 10 children were eventually transported home at county expense, 18 were transported at parental expense, and four were liandled by miscellaneous agency dispositions of the court.

Of the total delivered to the Probation Department during this period 309 were male and 101 were female.

50. Major targets were the university campus, Telegraple Avenue, and a section along University and Ashby Avenues where hitchbikers gathered.

51. While this was the typical procedure, according to police reports, officers happened upon youths in many other ways as well. For example, several predawn raids were conducted on so-called "crashpads," houses in which numerous youths were temporarily residing.

52. A peace officer may, without a warrant, take into temporary custody a minor:

(a) Who is under the age of 18 years when such officer has reasonable cause for believing that such minor is a person described in Sections 600 , 601 , or 602 . . .

CAL. Welf. \& INST'NS Code ANN. \& 625(a) (West Supp. 1971).

53. Section 625 of the Welfare and Institutions Code uses the term "temporary custody." Cal. Welf. \& INST'NS Code ANN. \$ 625 (West 1966). Penal Code section 625 describes an arrest as "an actual restraint of the person, or by submission to the custody of an officer." Cal. Penal CoDe $\$ 835$ (West 1972). The difference between "protective custody" and "arrest," however, appears to be primarily semantic. 
Once the child was taken into custody, the arresting officer would attempt to contact his or her parents, who would be advised that under California law it was unlawful for a juvenile under the age of 18 to travel freely in Berkeley or in California without a parent or responsible adult exercising control. If the parents resided in the Bay Area ${ }^{54}$ the child would be released to the parents. If not, the child would be delivered to the Alameda County Probation Department where a probation officer would determine how the child should be released, and the parents were so informed, providing they could be reached.

The juveniles were detained at separate facilities in the county. ${ }^{65}$ Each child would be interviewed by the "intake" probation officer, who would also contact the parents and request that they purchase a prepaid airplane ticket for their child. If the parents responded quickly, the youth would be released within 48 hours; if the arrest occurred on the weekend, however, detention would frequently extend up to four days. ${ }^{56}$ If the parents were indigent or unwilling to pay, a petition would be filed alleging jurisdiction under section 601 and requesting that the court order county funds to be made available to transport the child home. This process took two to three weeks but was rarely used since most parents were willing and able to pay the transportation costs..$^{67}$

At the beginning of the summer a few children were referred to runaway agencies. ${ }^{58}$ This permitted the child to remain in Berkeley under the auspices of the agency until arrangements could be inade for his return home or for some specified period determined by the parent. If the child's family knew a responsible adult who lived in the Bay Area, the parents could make arrangements with the probation officer to release the child to this adult. This family friend would then be responsible for sending the child home, and the child would be spared froin spending two to four days in the detention center.

54. This comprises the counties surrounding San Francisco Bay.

55. Boys were transferred to the Alaineda County Probation Department in Oakland, and girls were seut to the Juvenile Hall iu San Leaudro.

56. A minor taken into custody must be released within 48 hours unless a petition to declare him a ward of the court is filed. Since noujudicial days are excluded, a youth taken into custody on Friday eveuing may be held until Tuesday evening and still be within the 48 hour limitation. CAL. Welf. \& INST'NS CODE ANN. \& 631 (West Supp. 1971). In soine cases, the probation officer was unable to contact the pareuts and make arrangements for the minor to be returned home within the 48 hour time limit. In these situations, a petition was filed, but was later dismissed when the child was sent home.

57. See note 49 supra.

58. For example, Berkeley Runaway House or Huckleberry House, both private facilities. 
While the entire procedure was characterized by administrative efficiency, there was one major departure from normal procedures. Usually, a probation officer is allowed some discretion in determining whether a juvenile is actually "beyond parental control" or whether he can, in fact, care for himself. There was no such discretion, however, in these cases. ${ }^{59}$ The initial determination inade by the police officer was never questioned during the process, since the sole criterion for detention was presence in Berkeley without immediate adult supervision.

The majority of juveniles detained were middle-class whites with no ascertainable prior records, ${ }^{60}$ some were referred to in probation reports as "hippies." 61 The files indicate that there were three times more boys than girls ${ }^{62}$ detained by the juvenile authorities. ${ }^{63}$ Most of the girls were at least 16 years old, and only 10 were 14 or younger. More than half of the boys detained during the summer were at least 17 years old. Although apprehended as being runaways, most had some form of permission to travel, ranging from notarized letters from parents to oral permission. In some cases, the child left home without express consent but with the parents' knowledge. ${ }^{64}$

In some of the files parental reactions were noted. The reactions varied from that of one very distressed mother who had followed the advice of the school psychologist and allowed her son to "hit the road" to that of another mother who demanded that her son be given a hair cut before he was sent home. ${ }^{65}$ Several parents expressed their indig-

59. In some of the few cases that went before a juvenile judge, the judge would, if in his opimion the minor was capable of caring for himself and was close to 18, release the minor on his own recognizance. Where the parents were indigent or simply refused to pay for the minor's transportation home, petitions were filed and the court would order that county funds be made available to pay for transportation home. These cases, however, were very rare. See note 49 supra.

60. The primary means of determining this was the minor's own statement. In a few cases, however, it was determined that there was prior misconduct and that the minors were wanted in other jurisdictions.

61. In a federal action brought by the San Francisco Youth Law Center and the Berkeley Neighborhood Legal Assistance Office on behalf of parents and children, it was alleged that the police were enforcing the campaign only against those who fit the "hippie" description. Plaintiff's memorandum in support of application for temporary restraining order at 16, Youth Coalition for Self-Defense v. Berkeley Police Dep't, Civil No. 1682 (N.D. Calif., Oct. 20, 1970).

62. See note 49 supra.

63. Many of these youths were released immediately to their parents who resided in the area. Only those detained at one of the detention centers were included in the probation files.

64. In these cases the files indicated that the child had informed his parents, but the parents had not responded either positively or negatively.

65. These facts were taken from the reports of the probation officers who handled the cases. 
nation over the treatment received by their son or daughter. ${ }^{00}$ In some cases the police photographed and fingerprinted those detained, ${ }^{67}$ and records have been kept on all the youth detained by juvenile authorities. In light of the potential significance of such records and their abuse, ${ }^{68}$ the parents' concern was probably warranted. ${ }^{00}$

While Berkeley undoubtedly faced a particularly difficult situation with its transient population, it is also clear that many of those detained posed no threat whatsoever to themselves or to the city's welfare. $^{70}$ It is interesting to note that the police, whose standards to some extent coincided with those of the "child savers," directed their efforts primarily at hippies in need of "rehabilitation." The anomaly is that section 601-originally intended as a mechanisin for protecting children from harsh criminal courts-could so easily be used against youthful transients. This anomaly deinonstrates, though, that the procedures developed to aid the inoral purification of children can easily be stretched to cover a necessitous situation and thereby abused.

\section{III \\ The Underlying Constitutional Issues}

Statutes similar to California's have been subject recently to constitutional attack on the grounds of vagueness, ${ }^{71}$ and the danger of

66. Some parents were understandably unhappy about their son's or daughter's arrest. There is no evidence of physical abuse by any authorities, and there has been no known complaint to this effect. Many felt that the arrests were a form of harassment. On a few occasions there was open hostility by the youths toward the probation officer. On the other hand, some youths would state they were tircd of the "street life" and would express rehef at being sent home.

67. In most of the files the police report indicated that the youths had been photographed and fingerprinted.

68. See Hess \& LePoole, Abuse of the Record of Arrest Not Leading to Conviction 13, 1967 Crme and Delinquency 494; Note, Juvenile Delinquents: The Police, State Courts, and Individualized Justice, 79 HARv. L. Rev. 775, 784-87, 800 (1966). See also In re Gault, 387 U.S. 1, 18 (1967).

69. It is possible for a juvenile to have his records sealed. Regardless of whether a petition has been filed, five years from the date of disposition or upon reaching age 21 (whichever comes first) the minor Inay petition the court to have all of his juvenile records sealed, including those of law enforceinent agencies. CAL. WeLr. \& INST'NS CODE ANN. \$ 781 (West Supp. 1971).

70. Some of the files were incomplete, but as far as could be ascertained only 20 girls were true runaways, the others having some form of perinission to travel away from home. Over half the boys were over 17 , and most had soine form of permission to travel. Among the girls there were 11 petty offenses (typically shoplifting or panhandling) and three drug-related offenses. Ainong the boys there were seven drug-related offenses and 11 other criminal cliarges. There was nothing in most of the poice reports to indicate any need for intervention other than that the youth appeared to be under 18 years of age. Solne of the youths were either visiting friends or inerely passing through Berkeley.

71. See Gonzales v. Mailliard, No. 50424 (N.D. Cal. Feb. 9, 1971); cf. In re Gault, 387 U.S. 1 (1967); Kent v. United States, 383 U.S. 541 (1966). 
sacrificing procedural fairness in the interests of treating juvenile cases with individual discretion has been debated for decades. Even before the establishment of the first juvenile court in America, ${ }^{72}$ the Illinois supreine court in People v. Turner ${ }^{73}$ expressed its concern for catchall statutes. In that case, decided more than a century ago, the Illinois supreme court addressed the constitutionality of a statute permitting commitment to a reform school for anyone under 21 years of age who was "a vagrant or . . . destitute of proper parental care or . . . growing up in idleness or vice."74 The court struck down the statute, observing:

These laws provide for the "safe-keeping" of the child; they direct his "conmitment", and only a "ticket of leave", or the uncontrolled discretion of a board of guardians, will permit the imprisoned boy to breathe the pure air of heaven outside his prison walls. ... Such a restraint upon natural liberty is tyranny and oppression. If, without crime, without the conviction of any offense, the children of the state ate to be thus confined for the "good of society", then society had better be reduced to its original elements, and free governments acknowledge a failure. ${ }^{75}$

\section{A. "In Danger of Leading an Idle, Dissolute, Lewd or Immoral Life": The Early Approach}

Although the California supreine court has never passed directly on the constitutionality of section 601, there is some case law from the courts of appeal. The "idle, dissolute, lewd or immoral life" phrase of section 601 was first attacked in People v. Diebert, ${ }^{76}$ which upheld its constitutionality. In Diebert an adult was charged with violating fornier Welfare and Institutions Code section 702,77 which

72. The first juvenile court was established in Illinois in 1899. R. CAvaN, supra note 14 , at $234-36$.

73. 55 III. 280, 8 Am. R. 645 (1870).

74. Id. at $282,8 \mathrm{Am}$. R. at 647 .

75. Id. at 285-86, $8 \mathrm{Am}$. R. at 649-50.

76. 117 Cal. App. 2d 410, 256 P.2d 355 (2d Dist. 1953).

77. Ch. 369, § 702, [1937] Cal. Stat. 1937 (former Welfare and Institutions Code $\S 702)$ :

Any person who commits any act or omits the performance of any duty, which act or omission causes or tends to cause or encourage any person under the age of 21 years to come within the provisions of any of the subdivisions of section 700 or which act or omission contributes thereto, or any person who, by any act or omission, or by threats, commands, or persuasion, induces or endeavors to induce any person or ward of the juvenile court under the age of 21 years to fail or refuse to conform to a lawful order of the juvenile court, or to do or to perform any act or to follow any course of condnct or to so live as would cause or manifestly tend to cause any such person to become or to remain a person within the provisions of any of the 
made it a crime for any person to do any act that caused or tended to cause a youth under 21 years to come within the provisions of any of the subdivisions of then-section 700 (relating to jurisdiction over juveniles). ${ }^{78}$ The complaint against Diebert alleged that he had sold alcohol to three 17-year-old youths and that this had allegedly encouraged them to lead an "idle, dissolute, lewd or immoral life."70 Diebert attacked the constitutionality of the phrase on the ground that section 702 was too vague to constitute the basis of a criminal complaint and was, therefore, violative of the due process clause of the fourteenth ainendment. The Diebert court rejected this argument, concluding that simce the statute referred to section 700 it contained a reasonably adequate disclosure of what the legislature intended to proscribe. According to the court, the legislature intended that section 702 be given a "practical" construction, since it dealt with the problein of juvenile delinquency. Furthermore, the court suggested that such statutes should be upheld since their frequent use in penal statutes imdicated legislative assurance that they were understood by men of ordinary imtelligence. ${ }^{80}$ The Diebert court also rejected the argument that the trial court should have defined "idle, lewd, dissolute or immoral life" for the jury: "It is unnecessary . . . to define commonplace words which may normally be presumed to be within the understanding of jurors."

No modern court would accept Diebert's claim that these words have well-defined and common usages. However, Diebert did attempt to point out that some conduct is so clearly immoral as to provide unmistakable forewarning. For example, no one doubts that encouraging a juvenile to engage in crime would be comprehended by the statute. Moreover, simce the Alcoholic Beverage Control Act ${ }^{82}$ made it illegal for anyone under 21 to purchase or consume alcoholic beverages, Diebert had clear forewarning of the proscribed behavior, completely apart from the usages of the words. ${ }^{83}$

subdivisions of section 700 , is guilty of a misdemeanor. . . .

Section 702 has been replaced by Penal Code section 272, which preserves its general thrust. Cal. Penal Code ANN. $\$ 272$ (West 1970).

78. Ch. 369, § 700, [1937] Cal. Stat. 1937, renumbered CaL. Welf. \& INST'NS CODE ANN. \$\$ 600-02 (West 1966).

79. Car. Welf. \& INST'NS CODE ANN. $\$ 601$ (West 1966) (former $\$ 700(\mathrm{k})$ ).

80. 117 Cal. App. 2 d at 418,256 P.2d at 360 .

81. Id. at $422-23,256 \mathrm{P} .2 \mathrm{~d}$ at 363.

82. Cal. Bus. \& Prof. Code ANn. \& 25658(b) (West 1964).

83. Any on-sale licensee who knowingly permits a person under the age of 21 years to consume any alcoholic beverage in the on-sale premises, whether or not the licensee has knowledge that the person is under the age of 21 year, is guilty of a misdemeanor.

CAl. Bus. \& Prof. CODE ANN. \& 25658(c) (West 1964). 
Fourteen years later, In re Daniel $R^{84}$ presented the question whether the "idle, dissolute, lewd or immoral life" phrase is unconstitutional when applied to a juvenile. The petition alleged that the minor was in danger of leading a dissolute life in that he had adinitted selling marijuana on numerous occasions. The court rejected the argument that section 601 was unconstitutionally vague and said further that admission of a single sale of marijuana was sufficient to indicate he was in danger of leading a dissolute life. Therefore, if the conduct could be proven, a petition under either section 601 or 602 would be proper. ${ }^{85}$ Since the proof of the allegation rested solely upon the admission of the minor, however, the court reversed, loolding that proof of the allegations of a felony had to ineet the same standards as if the petition were under section $602 . .^{86}$

The Daniel court's dictum on the vagueness issue would unreasonably extend Diebert:

Language sufficiently definite to support conviction of a crime that has been punishable by a confinement for a period of two years is sufficient to define a condition that will subject a minor to the jurisdiction of the juvenile court.

It is reasonable that there be some method by which a juvenile may be made a ward of the court other than in a dependency situation (Welf. \& Inst. Code $\$ 600$ ) or when the commission of a crime can be proved (Welf. \& Inst. Code $\$ 602$ ). The language found in section 601 is no less satisfactory than 'growing up in crime', which is used in the statutes of several states. ${ }^{87}$

What would make this extension pernicious is the suggestion that evidence insufficient to sliow a criminal offense could nevertheless support a section 601 petition. Furtherniore, since prior federal court cases $^{88}$ had struck down language similar to that upheld in Diebert, it is surprising that none of these cases were mentioned in Daniel.

In Goldman v. Knecht, ${ }^{89}$ a federal district court held unconstitutional a vagrancy statute containing the phrase "leading an idle, immoral or profligate course of life." The court noted that the phrase failed "to establisl reasonable standards for determining guilt or innocence thus licensing the pohce, jury and judge to create their own standards," $" 90$ an argument rejected in Diebert. While a distinction can

84. 274 Cal. App. 2d 749, 79 Cal. Rptr. 247 (4th Dist. 1969).

85. Id. at 754, 79 Cal. Rptr. at 250.

86. Id.

87. Id. at 753,79 Cal. Rptr. at 249.

88. Ricks v. District of Columbia, 414 F.2d 1097 (D.C. Cir. 1968); Goldman v. Knecht, 295 F. Supp. 897 (D. Colo. 1969); Baker v. Binder, 274 F. Supp. 658 (W.D. Ky. 1967).

89. 295 F. Supp. 897 (D. Colo. 1969) (three-jndge court).

90. Id. at 904 . 
be made on the basis that Diebert involved criminal conduct and Goldman merely vagrant conduct, this distinction should not save section 601, since it has been applied even when no criminal conduct was proved. And it is this danger of application that calls for the elimination of such language.

\section{B. "Beyond Parental Control"}

The "beyond parental control" part of section 601 also raises constitutional problems. In In re David $S .{ }^{91}$ the issue was whether a single act was sufficient to constitute being beyond parental control. A 14-year-old was before the court on a petition alleging that he left his mother's home with permission to spend the weekend at Stinson Beach with friends. He went, however, to San Diego where he was subsequently apprehended attempting to cross the border into Mexico. On the basis of this one incident, the court found that he was beyond the control of his parents and, therefore, subject to the jurisdiction of the court pursuant to section 601 .

In holding this one act sufficient to bring the minor within the provisions of section 601, however, the court observed that section 601 may present some fourteenth amendinent problems:

[T]ts provisions must be construed with particular care. . . . [For] if the standards of conduct proscribed by section 601 are not carefully delineated, the statute could become a means of systematic discrimination against young people who are thereby denied equal protection of the law..$^{92}$

91. 12 Cal. App. 3d 1124, 91 Cal. Rptr. 261 (1st Dist. 1970).

92. Id. at 1127, 91 Cal. Rptr. at 263 (citations omitted). In re David S. was recently explained in In re D.J.B., 18 Cal. App. 3d 782, 96 Cal. Rptr. 146 (1st Dist. 1971). The petition there alleged that the girl in question had left home without her father's permission, and the juvenile court held that this was sufficient for it to assume jurisdiction under section 601. The court of appeal reversed on other grounds, but as an alternative holding it also considered the single act of leaving home:

Assuming that under the state of the record it can be said that appellant left her. father's home without his consent ... we must hold that such a single imstance of misbehavior cannot, as a matter of law, sustain a finding that appellant was a person who was beyond the control of her father.

$I d$. at $786,96 \mathrm{Cal}$. Rptr. at 149 . The court stated that such a single act could be sufficient if the minor had violated a law or a lawful order of the court, but that "this rule does not necessarily apply to proceedings pursuant to section 601 where the standards of conduct are not carefully delineated." Id. at 786, 96 Cal. Rptr. at 149. David $S$. was distinguished on the basis of the seriousness of traveling over 600 miles away from his home and attempting to cross the border mto Mexico. In In re D.J.B. the court found no cvidence that the minor's act was serious. Simply leaving home without permission, without other facts to show the seriousness of the act is not, according to the court, sufficient to sustain jurisdiction under section 601. Id. at 786-87, 96 Cal. Rptr. at 149. 
This dictum marks the first departure from previous decisions by California courts of appeal. The court further indicated concern about the possible shortcomings of the section:

We are also aware that the broad jurisdiction of the juveline court over noncriminal conduct has been currently questioned by some current evaluations. The 1967 Report of the President's Commission states at page 85: "Serious consideration at least, should be given to complete elimination of the court's power over children for noncriminal conduct." Fortunately, none of these issues are directly before us. ${ }^{93}$

\section{The Most Recent Approach}

A recent three-judge San Francisco federal court, in Gonzales $v$. Mailliard, ${ }^{94}$ recognized this danger and held that the "in danger of leading an idle, dissolute, lewd or immoral life" language of section 601 was unconstitutionally vague ${ }^{95}$ as applied to 10 youths charged with being in danger of leading such lives and "suspicion of robbery." The juvenile authorities sought to have these youths committed to the jurisdiction of the juvenile court. All of the charges against the youths were later dropped; nine of thein subsequently filed a coinplaint in federal court seeking a declaratory judgment that section 601 was unconstitutional, a permanent injunction against arrests under section 601, dainages, and an order expunging their records of arrest under section 601. The court unanimously granted part of the relief requested, noting that the "idle, dissolute, lewd or immoral life" phrase of section 601 was violative of the due process clause of the fourteenth amendment. Judge Wiegel's opinion for the court relied heavily upon several recently decided federal cases holding similar language in adult vagrancy statutes unconstitutional. ${ }^{97}$ In Ricks $v$.

93. 12 Cal. App. 3d at 1126 n.3, 91 Cal. Rptr. at 262 n.3.

94. No. 50424 (N.D. Cal. Feb. 9, 1971).

95. Id. at 12 . 1972).

96. The robbery charge was pursuant to CaL. Penal CoDe $\S 211$ (West

97. Ricks v. District of Columbia, 414 F.2d 1097 (D.C. Cir. 1968); Wheeler v. Goodman, 306 F. Supp. 58 (W.D.N.C. 1969) (three-judge panel); Goldman v. Knecht, 295 F. Supp. 897 (D. Colo. 1969) (three-judge panel); Baker v. Binder, 274 F. Supp. 658 (W.D. Ky. 1967) (three-judge panel).

Goodman declared a statute that allowed adults to be arrested for leading an "idle, immoral or profligate life" to be unconstitutionally vague. Goldman held a similar statute uuconstitutionally vague: "The term . . . 'leading an idle, immoral, or profligate course of life' is subject to the determination of the officer and his ideas as to what constitutes idle, immoral or profligate." 295 F. Supp. at 905 . The court noted that at the time the plaintiffs were arrested they were neither loitering nor strolling about. They were in a basement apartment described as a hippie hangout or hippie haven. In striking down this vagrancy statute, the court observed:

The circumstances which will invariably give rise to arrest and prosecution 
District of Columbia ${ }^{98}$ for example, the D.C. Circuit found that a loitering statute containing the phrase "leading an immoral and profligate life" was unconstitutionally vague:

Opposing segments of the general public may agree as to the immorality or profligateness of many activities. But, more importantly, it is expectable, if indeed not inevitable, that they will disagree on many others. ... [T] he phrase ... fail[s] to chart for the imdividual citizen the course that is proscribed .... [ []t also fails to mark out reasonably distinct boundaries for the judges and police officers who are required to administer the law..$^{99}$

In reaching its result, the Mailliard court refused to distinguish the vagrancy cases on the ground that section 601 was civil and not criminal. ${ }^{100}$ The Mailliard court noted that such a label, even if justified, would not rid section 601 of its vagueness. This position comports with A.B. Small Co. v. American Sugar Refining Co., ${ }^{101}$ where the United States Supreme Court rejected the criminal-civil distinction, a position that was later reaffirmed in Giaccio $v$. Pennsylvania: ${ }^{102}$

Whatever label be given the 1860 Act, there is no doubt that it provides the State with a procedure for depriving [a] ... defendant

are left to the discretion of the individual enforcing officer. Thus the manner of enforcement will always depend on the officer's subjective reactions to the conduct which he observes. Id. at 901-02.

The Kentucky statute in Baker v. Binder was similar to the North Carolina statute in that it was designed to deal with vagrants. In that case the plaintiffs had initiated and carried on demonstrations in the city of Louisville, Kentucky, designed to hightight discriminatory practices in housing in the city. In holding the statute unconstitutional the court noted:

This ordinance would punish a person who .... is unable to give a satisfactory account of himself. We do not beheve it can stand consistent with Shuttlesworth v. City of Birmingham, 382 U.S. 87, 90 (1965). To us it appears overbroad and vague. We do not beheve that the requirement that an offender "give a satisfactory account of himself" passes constitutional tests. It places sole determination in the discretion of the policeman on the beat. The standard of "satisfactory account" is not certain, for what nay be satisfactory to one may be unsatisfactory to another, and the meaning of the word "satisfactory" itself is not susceptible of any standard of exactness.

274 F. Supp. at 664.

98. 414 F.2d 1097 (D.C. Cir. 1968).

99. Id. at 1106-07.

100. Gonzales v. Mailliard, No. 50424 (N.D. Cal. Feb. 9, 1971), at 8. The state also argued that since all charges under section 601 had been dismissed before the lawsuit was filed, plaintiffs' suit was noot. The court noted, however, that the plaintiffs' class faced continued enforcement of section 601 and rejected the mootness argument. Furthermore, the court held that the plaintiffs should not have to violate the statute in order to challenge its constitutionality, especially since they were threatened with its enforcement daily. Id. at 3-4.

101. 267 U.S. 233 (1925).

102. 382 U.S. 399 (1965). 
of his liberty. ... [W] [Wether labeled "penal" or not [the statute] must meet the challenge that it is unconstitutionally vague. ${ }^{103}$

A critical factor in Mailliard was the seriousness of the deprivation of freedom possible under section 601.104 Unlike the California court of appeal in In re Daniel $R .,{ }^{105}$ where the court never mentioned the possible deprivations of freedom under section 601, Judge Wiegel emphasized that a youth adjudged a ward of the juvenile court under section 601 may be committed to a juvenile home or county camp. ${ }^{108}$ Furthermore, even though he did nothing that would be considered a crime if done by an adult, a youth could be committed to the California Youth Authority. ${ }^{107}$

The Mailliard court was also concerned about the effects of In re Winship ${ }^{108}$ on the vagueness of section $601 .{ }^{109}$ Winship held that

103. Id. at 402 .

104. It is now well settled that the more extensive the deprivation, the greater the due process requirement for certainty of statutory language becomes. See Jordon v. De George, 341 U.S. 223, 231 (1951); Winters v. New York, 333 U.S. 507, 515 (1948). Undoubtedly, the operative effect of section 601 can be one of serious deprivation.

105. 274 Cal. App. 2d 749, 79 Cal. Rptr. 247 (4th Dist. 1969).

106. See CaL. Welf. \& INST'NS CODE ANN. $\$ 730$ (West Supp. 1971).

107. See CAL. Welf. \& INST'NS CODE ANN. \$§ 601-02, 730-31, 777. Techmically, a minor can become a section 602 violator without violating a criminal statute. The language of section 602 states that a minor section 601 violator who subsequently violates an order of the juvenile court may, upon sustaining a supplemental petition, then be declared a section 602 violator. Thus, having done no more than disobey his parents, he may, under section 731, be sent to the California Youth Authority. Section 731 says that when a minor is found to be within the provisions of section 602 he may be subjected to the dispositions provided by sections 727 and 730 or, alternatively, may be committed to the California Youth Authority.

Section 730 specifically states that a minor declared a ward under section 601 may be committed to the California Youth Authority pursuant to the provisions of section 777. Section 777 provides for changing or modifying a previous order of the court and for directing commitunent to the Youth Authority when the previous disposition of the court "has not been effective in the rehabilitation of the minor."

108. 397 U.S. 358 (1970). The appellant, a 12-year-old New York boy, entered a school locker and stole $\$ 112$ from a woman's purse. The petition charging the minor with delinquency alleged that the act "if done by an adult would constitute the crime or crimes of larceny." The judge acknowledged that the proof offered did not establish guilt beyond a reasonable doubt but rejected the minor's contention that such proof was required by the fourteenth amendment. Instead the judge relied on a statute requiring that "[a]ny determination at the conclusion of [an adjudicatory] hearing that a [juvenile] did an act or acts must be based on a preponderance of the evidence." N.Y. FAMILY CT. ACT \& 744(b) (McKinney Supp. 1971-72). The minor was adjudged delinquent and placed in a training school for boys. The Court quoted the dissent in the New York Court of Appeals [W. v. Family Ct., 24 N.Y.2d 196, 207, 247 N.B.2d 253, 260 (1969) (Fuld, C.J., dissenting)]:

[W] here a 12-year-old child is charged with an act of stealing which renders him liable to confinement for as long as six years, then, as a matter of due process ... the case against him must be proved beyond a reasonable doubt.

397 U.S. at 368.

109. The court also suggested in dictum that two other portions of section 601, 
proof beyond a reasonable doubt is required when a minor is charged with conduct amounting to an adult crime. To illustrate the potential problem, suppose that a 17-year-old minor is arrested for forcible rape $^{110}$ but that the evidence is insufficient, to establish beyond a reasonable doubt that he committed the crime; no petition will then be filed under section 602. Under section 601, the minor could apparently be considered in danger of leading an idle, dissolute, lewd, or immoral life. But if such a broad cliaracterization is allowed, ${ }^{111}$ section 601 would render Winship virtually meaningless. What could not have been accomplished by the criminal law consistent with the procedural safeguards of Winship would become possible simply by proceeding under section $601 .{ }^{112}$ Indeed, Mailliard's refusal to give effect to such vague language seems not only correct but compelled.118

In sum, the Mailliard court took an enlightened and rational approach to a serious constitutional problein. ${ }^{114}$ It refused to adopt the

not at issue in that case, might present serious problems: that part referring to habitual disobedieuce of the "reasonable and proper" orders of parents and school officials, and that part referring to children who are "beyond the control" of their parents or school authorities. The problem of the former concerns its vague language; the problem of the latter, its failure to require a persistent lack of control. Judge Wiegel explicitly stated, however, that he was neither deciding nor implying that the legislature could not establish some form of protective custody if the standards were precise. Gonzales v. Mailliard, No. 50424 (N.D. Cal. Feb. 9, 1971), at 12 n.3. He continued:

But the parties have not squarely presented the issues raised by these other portions of $\$ 601$, and their own factual situation does not present an adequate case for consideration of these other portions, and we do not make a holding on them today. Nor do we find the statute so "indivisible" that the whole must fall with the part: See Decker v. Fillis, 306 F. Supp. 613, 617 (D. Utah 1969).

In so holding, we neither decide nor imply that the legislature is impotent to provide for some form of protective custody for delinquents or neglected juveniles, upon reasonably clear and definite standards, when it may be necessary for their own protection or that of society or of both.

110. See Cal. Penal Code $\$ 261$ (West 1972).

111. For a valuable discussion of possible uses of broad statutes, such as section 601, see Herman, Scope and Purposes of Juvenile Court Jurisdiction, 48 J. CRIM. L.C. \& P.S. 590, 593-95 (1958).

112. See Gonzales v. Mailliard, No. 50424 (N.D. Cal. Feb. 9, 1971), at 11-12.

113. See In re Winship, 397 U.S. 358 (1970); In re Gault, 387 U.S. 1 (1967); Kent v. United States, 383 U.S. 541 (1966). The teaching of Winship, Gault, and Kent is that fourteenth amendment due process is required in juvenile proceedings, regardless of how it is characterized.

114. The state also argued that the court should apply the doctrine of abstention, but this argument was rejected. After the Mailliard opinion, the U.S. Supreme Court in Younger v. Harris, 401 U.S. 37 (1971), held, on the basis of national policy for bidding federal courts to enjoin state actions, that a three-judge court must not stay or enjoin pending state court proceedings except under special circumstances. The Harris Court did not, however, express any "view about the circumstances under which federal courts may act when there is no prosecution pending in state courts at the time the federal proceeding is begun." $I d$. at 41 . In Milliard no proceeding was pending in juvenile court, all charges having been dismissed. 
traditional approach in dealing with the realities of juvenile justice; rather it looked to the requirements of due process. More importantly, it did not sustain Justice Tobriner's suggestive dictum in In re Gladys $R .{ }^{115}$ that perhaps the most important function of section 601 is to reach those youths not covered by section 602. As the Berkeley situation makes clear and as recent Supreme Court decisions indicate, due process demands notice and a showing of definite conduct before a person can be imprisoned or even "reformed" by the state. Thus, a court should have no jurisdiction over juveniles who have committed no definite criminal acts, unless they are in need of the protection afforded by the much narrower section 600.116 The problem of dealing with juvenile tendencies toward crime can be dealt with more effectively through agencies other than the juvenile courts. Hopefully, the sound approach of Mailliard will render section 601 obsolete.

\section{IV}

\section{SUGGESTED REFORMS}

In 1968 the Presidential Task Force Commission on Law Enforcement and the Administration of Justice conducted a study of current juvenile court systems and suggested major reforms. ${ }^{117}$ In particular, the President's Commission expressed concern over the broad classifications used in predelinquency statutes, ${ }^{118}$ which have "often become an anachronism serving to facilitate gratuitous coercive imtrusion into the lives of children and family."119 The Commission felt that the phrase "beyond control" sliould mean defiance of parental authority, ${ }^{120}$ but it went further than suggesting more rigorous definitions. Unlike the early reforiners, the Commission recognized that delinquency is as much a product of societal conditions as it is a behavioral problem and that the only rational way to approach the overall problems of delinquency is to deal not only with behavior but also with the conditions that underlie beliavior. ${ }^{121}$ As a minimum,

115. 1 Cal. 3d 855, 865 n.20, 464 P.2d 127, 135 n.20, 83 Cal. Rptr. 671, 679 n.20 (1970).

116. CAL. Welf. \& INST'NS CODE ANN. $\$ 600$ (West 1966), reproduced in note 1 supra.

117. President's Comm'N on Law Enforcement and the Administration of Justice, Task Force Report: Juvenile Delinguency and Youth Crime 25, 27 (1967) [hereinafter cited as TASK FORCE REPORT].

118. See Herman, Scope and Purposes of the Juvenile Court Jurisdiction, $48 \mathrm{~J}$. CRIM. L.C. \& P.S. 590 (1958).

119. TASK FORCE REPORT 84.

120. PREsident's COMn'N ON LAW ENForCement and Administration of Justice, The Challenge of Crime in a Free Society 84 (1967) [hereinafter cited as The Challenge of Crime in a Free Society].

121. Id. at 85 . 
the Commission suggested that the predelinquent category be narrowly circumscribed and that serious consideration be given to the complete elimination of noncriminal behavior from the court's jurisdiction. ${ }^{122}$ As an alternative, it proposed the creation of community-based youth service bureaus to serve the counseling function courts now attempt to provide. ${ }^{123}$

Other reform movements have been preoccupied with the social stigma of the term "delinquency." But rather than circumscribe the meaning of predelinquent behavior, such reforms are aimed merely towards the elimination of the delinquency label. The effect is usually to create another label for the predelinquent class. ${ }^{124}$ The revised Standard Juvenile Court Act, ${ }^{125}$ for example, supports the basic concept of parens patriae, but, since the 1959 revision, avoids use of the terms "delinquency" and "neglect." A similar approach was advocated by the New York Joint Legislative Committee on Court Reorganization in its draft of a Family Court Act. The committee defined a "juvenile delinquent" in the proposed legislation as "a person over seven and less than sixteen years of age who does any act which, if done by an adult, would constitute a crime and requires supervision, treatment or confinement."126 The New York statute refers to the child with only a potential towards delinquency as "a person in need of supervision" (PINS) ${ }^{127}$ While it was hoped this would reduce the stigma and the numbers coming before the court, studies show the opposite effect. ${ }^{128}$ The need for an alternative approach is apparent; a name change does nothing to remedy the crucial problem of preventing future delinquent behavior.

\section{A. Youth Service Bureaus}

Youth service bureaus ${ }^{129}$ are community-based service agencies where children may be referred provided their behavior has not mani-

122. TASK FORCE REPORT 27.

123. The Challenge of Crime in a Free Society 83.

124. See Comment, Juvenile Justice in Transition, 14 U.C.L.A. L. REv. 1144, 1149 (1967).

125. Standard Juvenile Court Act, 5 Nat'l Probation and Parole Assoc. J. 344 (1959).

126. See Sellin \& Wolfgang, The Legal Basis of Delinquency, in DeLInQuency AND Social Policy 25 (P. Lerner ed. 1970).

127. "Person in need of supervision" means a male less than 16 years of age or a fenale less than 18 years of age who is an habitual truant or who is incorrigible, ungovernable, or habitually disobedient and beyond the lawful control of parents or other lawful authority. N.Y. FAMIIY CT. ACT $\S 712$ (b) (McKinney Supp. 1971-72).

128. See Lemer, Beyond Gault: Injustice and the Child, in DeLINQUENCY AND Social Policy 236, 243 (P. Lerner ed. 1970). See also H. James, Chimdren iN Trouele: A National Scandal 23-24 (1970).

129. See note 123 supra. These bureaus would offer services for section 601- 
fested a serious threat to themselves or to society. The primary purpose of the youth service bureau is to offer services to youth whose conduct indicates a need for assistance, and at the same time to offer services to petty offenders who do not appear to be appropriate subjects for juvenile court action. For instance, truants, incorrigibles, runaways, children found in disreputable places, petty offenders, and those who for some other reason appear to be in need of assistance would be referred to the bureaus. ${ }^{130}$

The juvenile court should be viewed as a place of last resort, ${ }^{131}$ dealing only with children who have violated criminal statutes and who do not appear amenable to other treatment processes. This would be in contrast to the present policy of referring section 601 cases to juvenile authorities to receive treatment through probation departments or social agencies. ${ }^{132}$ This approach has crowded court

type and other minor referrals. See also Boches, Juvenile Justice in California: A Re-evaluation, 19 HASTINGS L.J. 47 (1967):

If and when Youth Service Bureaus as suggested by the President's Com-

mission are established, elimination of section 601 jurisdiction entirely may well be in order.

Id. at 71. Some writers have viewed this approach cautiously. For example, one commentator who criticizes the traditional approach taken by the "child-savers" and suggests that informal agencies of social control should be developed nevertheless expresses some concern about the youth service bureau concept: "It is difficult to see how proposals such as the Youth Services Bureaus will eliminate arbitrary and third-rate practices in agencies." Platt, Serving and Controlling Delinquent Youth: A Critique, 5 Issurs in Criminology 1, 20 (1970).

130. According to the President's Commission:

The conduct-illegal-only-for-children category of the court's jurisdiction should be substantially circumscribed so that it ceases to include such acts as smoking, swearing, and disobedience to parents and comprehends only acts that entail a real risk of long-range harm to the child, such as experimenting with drugs, repeatedly becoming pregnant out of wedlock, and being habitually truant from school. Serious consideration, at the least, should be given to complete elimination of the court's power over children for noncriminal conduct.

The Challenge of Crme in a Free Society 85. See also Correction in the United States: A Survey for the President's Commission on Law Enforcement and Administration of Justice 13 CRIME AND DELINQUENCY 1 (1967):

However, also referred to the Court and probation department in many jurisdictions are numbers of confused, disturbed, or unfortunately situated children whose actions would not be considered violative if done by an adult. Frequently these children are "at war with themselves," not "at war with society." Yet to be resolved is the question of whether these children also are to be considered the proper responsibility of probation and the correctional system. It is within that system that they are often given the only service they get-but this is often by default, a product of the failure of the community to provide alternatives for diversion of such children from the correctional system.

Id. at 68-69.

131. See Note, $A$ Proposal for the More Effective Treatment of the Unruly Child in Ohio: The Youth Service Bureau, 39 U. CIN. L. REv. 275, 282 (1970). See also TASK FORCE REPORT 26.

132. See CaL. Welf. \& INsT'Ns Code ANN. $\$$ 725(a) \& (b), 727(b), 730 (West 
dockets and usually failed to rehabilitate the child; ${ }^{133}$ more important$1 y$, it places social stigma on the child. As one former juvenile court judge recently remarked:

What happens to the 601's? They are detained and sent to 'facilities'-i.e., institutions or jails. Neither their friends and relatives nor the public make any distinction whatsoever between an incorrigible, a 'beyond control,' or a delinquent. In the final analysis, we can-and do-deprive the minors of their freedom in the 601 process. ${ }^{134}$

Even the referral by a court to other social agencies is often unsuccessful because it is involuntary. ${ }^{135}$ When a referral is coercive, the client lacks the motivation necessary for successful "problem solving."130

The youth service bureau concept permits the police, school authorities, parents, and private complainants to refer youths directly to the bureau, where qualified personnel will evaluate and treat the youth on a voluntary basis. By eliminating section 601 referrals, this approach would greatly reduce the number of youths referred to the juvenile court, leaving the probation department free to deal with seriously delinquent children. The President's Commission suggested that youth service bureaus be within the local community where the parents and child can voluntarily seek the services of a professional agency. ${ }^{137}$ These agencies would be required to accept all children who now fall into the present category of section 601; the juvenile

Supp. 1971). After a minor has been declared a ward of the court pursuant to section 601 , the court in its discretion 1nay commit the youth to "[s]ome association, society, or corporation embracing within its objects the purpose of caring for such minors, with the consent of such association, society, or corporation." [id. $\$ 727$ (b)] or to "[s]ome reputable person of good moral character who consents to such commitment" [id. $\$ 727(\mathrm{a})]$

133. See Bazelon, Beyond Control of the Juvenile Court, 21 Juv. Cr. JudaEs J. 42,44 (1970):

[I]n the area of borderline pre-delinquent jurisdiction-beyond control, truancy, and the hike-where the rationale for intervention seems to be the illusory hope of preventing future crimes, we ought to stop fooling ourselves and the community. You ought to tell the community that you are failures ... at preventing dehinquency and crime. As long as the community views you as a prevention agency and refers its social and behavioral problems to you, the root problems will not be attacked.

134. MacFaden, Changing Concept of Juvenile Justice, 17 CRIME AND DeLINQUENCY 131, 137 (1971).

135. The prevailing view in the field of social work is that an involuntary client is the least preferable and is least likely to be benefited by such services. H. PeRLman, SOClal CaSEWORK 130-31 (1957).

136. Cf. H. PerLman, supra note 135, at 130-38. See also Rosenhein, Youth Service Bureaus: A Concept in Search of Definition, 20 Juv. Cr. Judoes J. 69, 71 (1969).

137. The Challenge of Crime in A Free Society 83-84. 
court would not have original jurisdiction over these children. ${ }^{138}$ As Judge Bazelon argues:

The youth who cannot make it with his own parents needs a room at the $\mathrm{Y}$, a foster home, a supervised shelter, or some sort of home substitute that will work for him. And the parents who [cannot] handle him may well need counseling or other assistance themselves. If the juvenile court had no jurisdiction to commit children in such situations, the community would have to come up with a solution. Neither the parents nor the community need to look for solutions, while the juvenile court is available. ${ }^{139}$

Procedurally, the youth service bureau would work as follows: The child and parents, working with the agency, would be given approximately 4 to 8 weeks to formulate a mutually acceptable plan of treatment. If none can be devised within that time, the bureau would report its findings to the referring agency. And, if no agreeable plan can be worked out, the contact with the bureau would be terminated and no further action taken, unless the initial referral to the agency was for a violation of a criminal law. In such a case the initial referring agency would have the option of referring the matter to juvenile court under section $602 . .^{140}$

A wide range of services could be offered by the youth service bureau, including remedial education, psychiatric diagnosis and treatment, and group and family counseling. Volunteers from the community could be solicited to aid in the treatment process, though the agency should not becoine simply a coordinator of existing services. Rather, it should seek to develop those services lacking in the community in order to ensure a comprehensive program. This is not to suggest that the agency should not play any role at all in coordinating existing services, but rather that the primary focus should be the dispensation, not the administration, of services. Therefore, for any agency to be effective, it must be able to offer short-term, crisis-oriented casework, as well as long-term casework. ${ }^{141}$ Finally, youth service bureaus should strive to develop programs ${ }^{142}$ that allow

138. Rosenheim, supra note 133 , at 71 .

139. Bazelon, supra note 133, at 43.

140. See Note, supra note 127, at 284.

141. See Sheridan, Juveniles who Conmit Noncriminal Acts: Why Treat in a Correctional System?, 31 Fed. Probation, 26, 28 (March 1967).

142. These youth service agencies should be especially effective in dealing with truants since, inore than other potential delinquents, they require individual treatment. Truancy has heretofore been handled in the juvenile court; and, on some occasions, youths have been committed to a county camp or, under preseribed procedures, to the Youth Authority. Cf. note 105 supra. Such quasi-criminal measures for what is essentially a social or environmental problem seems senseless since a Youth Authority commitment is not likely to produce the desired results. Sending a youth 
people in the community to be involved in all aspects of the treatment process, for youths may respond more favorably if they know their neighbors are genuinely interested in their development.

\section{B. A Community Youth Responsibility Program}

San Mateo County, California, has instituted a project in East Palo Alto known as the Community Youth Responsibility Program. ${ }^{143}$ Receiving soine of its ideas froin the youth service concept, the project is a community-based venture designed to provide a different type of service to local youth involved in asocial behavior that may lead to juvenile court appearances and probation status. ${ }^{144}$ In addition, the project involves youths who have violated criminal statues. ${ }^{145}$

The purpose of the project is to reduce crime by involving the East Palo Alto community in the prevention of juvenile crime. It is sponsored by the East Palo Alto Municipal Council, an agency of the county. ${ }^{146}$ The inembers of the council are elected by voters of the

to a county or state institution may be a short-term expedient, but the basie problem is likely to remain unresolved.

Cognizant of section 601's inadequacy for dealing with truants, the California Legislature recently attempted a response. A proposed assembly bill called for amending section 600 to include truants under the dependency category. Asseinbly Bill No. 412 (amended in Assembly, March 29 and April 15, 1971). It failed to be enacted into law. This proposal would have removed soine of the stigma, and it would necessarily have meant that a truant would no longer be sent to a connty camp or state institution. It would not, however, have dealt adequately with the cause of truancy. A more pragmatic solution would be first to require an agency such as the youth service bureau to try to rectify the problem; only upon proof of failure should dependency proceedings be initiated. Ideally, truants should be handled as other noncriminals by a referral to a youth agency within the coinmunity. Therefore, education should be a part of any effective youth prograin, and it should encompass all segments of the community, with the dispensation of services dependent upon the direct involvement of the meinbers of the local community.

143. The project is funded through the California Council on Criminal Justice, the state agency that administers all federal funds received for criminal justice. The project's grant is under section 301(b) of the Omnibus Crime Control and Safe Streets Act of 1968, 42 U.S.C. $\$ 3731$ (b) (9) (1971).

144. A situation can develop where a 16- or 17-year-old adolescent dccides to leave home and go out on his own without any supervision whatsoever. Is society willing to permit this kind of a situation? Probably not. To do so would appear to be unfair to the adolescent as well as to the parents who still may be held responsible for his care, supervision, and conduct. It is also unfair to the community since in such situations the adolescent's conduct may indicate a drift toward criminal acts. ... [E]xperience has shown that it cannot be assumed that parents are always acting in the best interest of the child.

Sheridan, Juveniles Who Commit Noncriminal Acts: Why Treat in a Correctional System?, 31 Fed. Probation, 26, 28 (March 1967).

145. These are mainly youths on probation or parole.

146. R. Evans, Community Youth Responsibility Program's Application for Funding, 1971-1972, at 8 (available from Robert B. Evans, Project Director, 2220 University Avenue, East Palo Alto, California 94303). 
community in general elections. ${ }^{147}$ The operation of the project involves members of the local community, as block volunteers, district coordinators, and project supervisors. Youths who enter the program, upon referral from various community agencies, parents, and schools, receive counseling and are involved in various community activities. This avoids placing juveniles on probation or giving them a court record.

The unique feature of this project is the degree of community authority. Young people who have committed serious acts, who are repeatedly involved in difficulty, or who have revealed problems requiring efforts beyond the project staff are brought before a community panel. ${ }^{148}$ This hearing works as a supplement to the youth guidance phase designed to avoid the necessity of a juvenile court hearing and disposition. But, more importantly, it focuses community authority on the acts of the youthful offender. ${ }^{149}$ The community panel is made up of responsible neighborhood people, including juveniles, appointed by the Community Youth Responsibility Program Board of Directors and the Municipal Council. ${ }^{150}$ A panel reporter gathers information concerning the alleged conduct of the minor, makes it available to the panel, and brimgs concerned parties before the panel.

If the community panel finds the minor responsible for a significant law violation, the offender is required to perform useful community work under the supervision of the work supervisor. The legal basis of the community panel's decision is the voluntary acceptance by the minor and, where appropriate, the victim. Should the minor simply refuse to obey, and if the initial referral was made by the sheriff's department for a criminal violation, the matter is referred back to the sheriff, who then decides whether the matter should be referred to the probation department. ${ }^{151}$

147. Id.

148. Id. at 9.

149. The program's coordinator reports:

Community residents . . . are beginning to cooperate with law enforcement by reporting burglaries, identifying people involved in crimes, and going into court as witnesses. This type of cooperation is rare in Black communities. However, because people are now willing to cooperate, the instance of crime Id. at $9 \mathrm{~b}$. reporting is higher.

150. The community panel uneinbers became a functionnig unit at the end of Decenber 1970. During the mouth of Jauuary 1971, the 10 members (six adults and four youths) involved theinselves in a great deal of training to learn the ways of the traditional juvenile systems. Therefore, they visited unost of the juvenile facilities in the county. They attended many lectures and conferences with judges, referees, court officers, juvenile hall counselors, and cainp counselors. Their training coutinues to be an ongoing process. $I d$. at $8 I-8 \mathrm{~m}$.

151. Id. at $8 \mathrm{~b}$. 
While complete evidence is lacking, some observations can usefully be made. The number of youths in the program is approximately 65 . The offenses of these youths include truancy, incorrigibility, burglary, shoplifting, assault, mischievious conduct, possession of a loaded weapon, possession of marijuana, filing a false police report, and running away. Referrals have come from several sources including the sheriff's department, the San Mateo and Santa Clara County probation departments, the welfare department, local schools, and individual parents on a walk-in basis. Significantly, the number of burglaries has markedly decreased from 158 in January 1971, when the program began, to 67 in June $1971 .^{152}$ With the program functioning throughout the commumity to inform citizens of crime in the area, ${ }^{163}$ and with the number of youths who might normally be imvolved in burglary attending school more regularly than previously due to the efforts of the youth guidance center, it is reasonable to assume that some of the goals of this program are being met.

In the future, the focus of the program will be widened. Various group meetings attended by school personnel ${ }^{154}$ and students have been planned to discuss school behavior and truancy problems, and a psychiatrist has volunteered his services for a study of the whole range of problems afflicting troubled youth. In addition, the block volunteer unit plans to develop a mini-economic corporation to be run solely by youth with adult guidance. There are also plans, in conjunction with Canada College and Community Youth Responsibility Program, to implement an effective parent-training program in an attempt to eradicate some of the difficulties that begin in the family and culminate in acts agaimst society. ${ }^{15,5}$

\section{California's Experiment With Youth Service Bureaus}

The Youth Service Bureau Act was passed in July 1968 by the

152. Id.

153. Block volunteers have actively disseminated crime prevention information throughout the area via meetings and home calls. Reportedly, the block volunteer units have been quite effective in assisting the community to change its attitudes about burglaries and police cooperation. Also the block volunteer units have involved themselves in various youth activities. They have attcmpted to create new youth concepts in the area and have eooperated with existing youth organizations in promoting various prograins. Id. at 9.

154. In the early stages the project realized that the schools were of utmost importance. They have worked closely with the schools in attempting to solve the truancy problems. Now, before there are any truancy hearings by the school district, the Community Youth Responsibihty Program is given an opportunity to work with the youth. The normal procedure would be for the youth to attend a truancy hearing and then be referred to the probation department. Id. at $9 \mathrm{~b}$.

155. Id. at $9 \mathrm{c}$. 
California Legislature, ${ }^{156}$ providing for the establishment of four pilot youth service bureaus at the local level. After the Youth Service Bureau Act was signed into law, the California Delinquency Prevention Commission, local county delinquency prevention commissions, and staff from the Department of Youth Authority establislied standards and guidelines for youth service bureaus. ${ }^{157}$

The purpose of the Act was to bring existing services and resources within the framework of a single facility and organizational structure as a means of providing coordination of efforts and reducing delinquency in the project areas. ${ }^{158}$ Coordination of existing services and resources was the main function of the bureaus. ${ }^{159}$

A youth service coordinator selected by the county delinquency prevention commission was in charge of each youth service bureau. ${ }^{100}$

156. CAL. WeLf. \& INST'NS Code ANN. $\$ \S 1900-06$ (West Supp. 1971).

157. California Delinquency Prevention Commission, Youth Service BuREAUS, STANDARDS AND GUIDELINES 6-7 (1968), sets forth the commission's standards and guidelines:

The purpose of the Youth Service Bureaus Act is to offer an incentive and opportunity for local agencies (both public and private) to pool their resources and develop innovative prograins to divert young people from entering into the juvenile justice system. The Youth Service Bureau is a place in the community to which delinquent and delinquent-prone youths can be referred by parents, law enforceinent agencies, the schools, etc. It should have a wide range of services reflecting the coordination and iutegration of important public and private prevention resources existing in the community.

A neighborhood center is envisioned in a location central to the coinununity (or to a target area within the community), with day-to-day operations and services under the direction of a Youth Services Coordinator. Participating agencies, organizations and volunteers would contribute full or part-time staff and supportive services for the children and youth served.

The number and types of services which can be provided through a Youth Service Bureau are limited only by the imagination of local individuals who are responsible for the program and/or by the willinguess of various public agencies and private organizations to commit themselves to a cooperative effort. The Youth Service Bureau concept asks those agencies, organizations, and individuals in a community who are involved in delinquency prevention to inventory, organize, and coordinate their resources in an exploration of new avenues of referral, education, and treatment adapted to meet the unique problems represented by delinquency in their community.

These standards and guidelines do not attempt to spell out specific services which should be offered through a Youth Service Bureau. This is nost properly a inatter to be determined at the local level, by the staff and managing board of each Youth Service Bureau in cooperatiou with agency adininistrators and citizen groups. This position is reinforced by the fact that the incidence and characteristics of delinquency, as well as the quantity and kinds of resources available to combat it, will vary greatly among connmunities. - By design, the standards do not dictate the structure or staff composition of these Youth Service Bureau pilot projects. The two primary principles underlying this law are flexibility and local control.

158. CAI. Welf. \& INST'NS Code ANN. \$ 1900 (West Supp. 1971); see Dep'T of Youth AuthortTy, Youth Service Bureaus: A First-Year Report to the CALIFORNIA Legislature 2 (1970).

159. See CAL. Welf. \& InsT'Ns Code ANN. \& 1903 (West Supp. 1971).

160. Criteria for his selection were his education, community experience with 
A managing board was selected for each bureau. Generally, the boards represented a blend of public officials, employees of public agencies and private organizations that offer services to youth, and area residents. Area residents comprised at least 20 percent of each board's membership. ${ }^{101}$ Some public agencies invested time and support, in addition to loaning staff members to the bureaus on a partor full-time basis. Support, including some financing froin these agencies, was usually strong. Private organizations such as the Y.M.C.A., the Y.W.C.A., religious groups, and representatives of ethnic minority groups participated in the bureaus. Volunteers, including professional social service workers and college and high school students also participated in the program. In some instances, the bureaus received outside funds and resources. ${ }^{162}$

To be totally effective, youth service bureaus should offer programs that are innovative, practical, and readily accessible to the community. California's focus was on the coordination of those delinquency prevention services and resources that constituted direct services to youth and community education. ${ }^{163}$ The coordinator had to determine which services were available in the community and, alternately, which essential services were absent. Channels of communication with people in the community were set up in order to obtain the cooperation of the community in a common cause. If there was an insufficiency of existing services available for youths, the coordinator atteinpted to establish some order of priorities. However, because of the inadequate financing, ${ }^{164}$ only limited direct services could be

youth programs, familiarity with the police and court system, ability to understand multi-approaches to social problems, and ability to work effectively with different agencies.

161. Dep'T of Youth AUTHORTTY, supra note 157, at 5.

162. Id. at 8.

163. To give a more complete picture of the process by which a youth was referred to the bureaus, consider the procedure used in San Jose (Santa Clara County), California. The policy of the San Jose police department's juvenile division was to refer cases to the youth service bureau if it believed they were in need of followup or counseling but were not of a serious nature. Only youtl without prior police contact, lowever, were referred. After the mitial police investigation, the police officer would notify the minor and his parents that the case would be referred to the youth service bureau; he requested that they cooperate with the bureau. The police report was then forwarded to the youth service bureau, which requested in writing that the parents bring the youth to the bureau. If there was no response within 5 days, the bureau telephoned the parents; if the parents still refused to respond, the bureau then asked the police not to refer the minor to the bureau again. DEP'T OF THE YOUTH Authority, Youth Service Bureaus-Progress Report 11 (Dec. 3, 1970).

164. Inadequate funding perhaps inore than anything else can effectively stifle any ineaningful program. This is especially noted when the government funds programs for black residents. As Mr. Ecliols correctly asserts:

The fimal attribute is permanence. A large number of tribute prograins in

The Black Community are projects funded by government or foundations for a 
offered. $^{165}$

In sum, the California youth service bureaus, despite their meager funding, ${ }^{166}$ attempted to institute programs ${ }^{167}$ that could have offered services without the coercive atmosphere and stigma of the juvenile court. $^{168}$ Several of the bureaus claimed that the response from youths was very favorable; in fact, youths actively sought the services of the bureaus. But despite these favorable results, the legislature did not elect to contimue the project. ${ }^{169}$ Whether the legislature will pursue similar programs in the future on a local or state level remains doubtful. ${ }^{170}$

given number of years-sometimes only a year-sometimes only a summer, a short, [cool] summer, we all hope. The funding runs out and it's time to write the next proposal for the next program.

Echols, Deadline, Vengeance, and Tribute-A Prescription for Black Juvenile Delinquency, 16 CRMP AND Delinguency 357, 362 (1970). For the operation of the four original pilot projects the legislature appropriated $\$ 100,000$, which constituted the total budget for all four.

165. Some bureaus, however, managed to develop some very interesting programs. For example, in Pacifica, California, a street-worker delinquency prevention project, which attempted to contact the uninvolved, alienated youth who in previous summers had become involved in serious imcidents of delinquency. The purpose of the contacts was to provide these youths with an opportunity to vent their frustrations and problems and to divert thein into positive activities. DEP'T OF THE YOUTH AUTHORITY, supra note 163 , at 9.

166. It is interesting to note that the average cost per occupied bed at the California Youth Authority in $1968-69$ was $\$ 5,779$ and the average period of institutionalization was 9.9 months for boys and 8.6 months for girls. DeP'T of YouTr Authortty, ANnual Statistical Report 34, 35 (1969). Because of the totally inadequate financing of the bureaus-each received approximately $\$ 25,000$ annually-it is amazing that soine of the bureaus were able to funetion as well as they did. If the legislature were willing to put similar amounts of money into the youth service bureaus as it has into enforcing section 601, the bureaus could have a greater impact and ultimately become able to deal with section 601 offenders as well as some minor section 602 violators.

167. Many of the bureaus offered tutoring, summer youth employment service, "rap sessions," psychiatric therapy groups for drug users, foster home recruiting, recreational activities, and adult education courses on how to deal with youth. DEP'T of YoUTH AUTHORITY, supra note 157, at 5.

168. There is great concern about the harmful effects of the juvenie court:

But more importantly, the nondelinquent juvenile who is . . . subjected to the comparatively bleak and authoritarian atmosphere of most juvenile facilities, harboring natural feelings of imdignation and frustration toward the adult world for his unjust treatinent, will be forced to associate with delinquents at an age when he is extremely susceptible to peer influence. The concession that the system may help a juvenile . . . cannot be taken to mean that the system will not harm a youth who is not an offender.

Comment, Juvenile Justice in Transition, 14 U.C.L.A. L. REv. 1144, 1149-50 (1967). 169. See CaL. Welf. \& Inst'NS COde ANN. \& 1902 (West Supp. 1971). The projects were scheduled to terminate on the 61st day after adjournment of the 1971 regular session of the legislature.

170. A final report on the bureaus will be given to the legislature during the 1972 session. CAL. Welf. \& IsNT'NS COde ANN. \$ 1902 (West Supp. 1971). 


\section{CONCLUSION}

The present reach of section 601 is too broad. There are some indications, however, that legislative change may be forthcoming: ${ }^{171}$ a specific proposal to amend section 601 reads as follows:

Any person under the age of 18 years who is beyond the control of his parents, guardian, or custodian, because of his persistent and habitual refusal to obey the reasonable and proper orders or directions of such person, is within the jurisdiction of the juvenile court which may adjudge such person to be a ward of the court.172 If the phrase "in danger of leading an idle, dissolute, lewd or immoral life" were deleted, as the proposal recommends, the abuses of the Berkeley situation could not be repeated, since juridiction under section 601 would be proper only if there were a complaint from the parent, guardian, or custodian of the minor alleging that the minor was beyond his control. But even this narrower version of section 601 would still allow the juvenile court to exercise jurisdiction over a youth who has not commited a crime. And even though the proposal might eliminate abuse by police, it would still allow parents or guardians to resort to juvenile court when they become frustrated im their own efforts to control their children. ${ }^{173}$ Furthermore, the "reasonable and proper" phrase is vulnerable to attack on vagueness grounds, as in Mailliard, since section 601 does not purport to define what would be a reasonable and proper parental order. ${ }^{174}$

Therefore, the legislature should repeal section 601 in its entirety, and programs such as the youth service bureaus or the Community Youth Responsibility Program should be funded by the state and implemented locally in each county. Of course, such a proposal would involve the expenditure of substantial revenue, but it must be remem-

171. In February 1971, a bill was introduced into the California Assembly to repeal section 601. The Assembly rejected the proposal. After the rejection, however, the Asseinbly committee recommended amending the section. Assembly Bill No. 412 (amended in Assembly March 20 and April 15, 1971). The bill was later referred back to committee for interim study.

172. Id.

173. Judge Zehler writes:

It grows inore difficult to preside over an adversary proceeding when the youngster is petitioned by his parents, or the school, for being beyond their control. ... [The] child is not accused of any criminal act. He is generally not hurting anyone but himself. If he or she vere beyond the age of the juvenile court law, he or she would not be before any court, and in ... such cases, it's not a proper case for the court to start with. A careful intake screening should divert this child to the proper nonjudicial agency for counselling and treatment.

Zehler, One Judge's View of the Juvenile Court, Post Gault, 21 Juv. CT. JUdors J. 112, 113-14 (1971).

174. Cf. Tappan, Judicial and Administrative Approaches to Children with Problems 156-57, in JUSTICE FOR THE CHILD (M. Rosenheim ed. 1962). 
bered that the counties and the state spend a great deal of money each year implementing section 601 . From a practical viewpoint, such an approach is reasonable because it is based on the recognition that children who have not violated penal statutes should not be treated as if they had. ${ }^{175}$ Further, it does not require that children appear in court and be adjudicated wards of the court and possibly sent off to an institution when they have actually not violated any law for which an adult could be convicted. In addition, and perhaps of utmost importance, this approach would relieve the probation officer of a tremendous, time-consuming burden-the supervision of the incorrigible or runaway youth-leaving more time to concentrate on the seriously delinquent.

Robert L. Harris

175. Most of the commentators in this area suggest that a completely new approach be taken. But none suggest abandoning the child altogether. See, e.g., Platt, supra note 129, at 14:

Locally-based, specialized, and informal agencies, using casework techniques, should be establislied to supervise marginal offenders and adolescents who, if left unchecked, are likely to commit serious delinquencies. in the future.

Nevertheless, Platt is very skeptical about the operation of youth service bureaus, for he fears that, although they may have good intentions, they may still be susceptible to the same abuses that have come out of the use of section 601. Id. at 20. 